\title{
Transnational migration, refugee studies and lifelong learning
}

\author{
Shibao Guo ${ }^{1}$ (D) \\ Published online: 29 January 2022 \\ (๑) UNESCO Institute for Lifelong Learning and Springer Nature B.V. 2022
}

The COVID-19 pandemic has presented unprecedented challenges to the globalised world, disrupting our lives and reconfiguring the world we live in. It has also caused feelings of isolation, stress, fatigue, uncertainty, anxiety and depression. The impacts of the pandemic have also extended to the movement of people across transnational borders, with wide ramifications and social consequences. Since the World Health Organisation declared the outbreak of COVID-19 a global pandemic on 11 March 2020 (WHO 2020), ${ }^{1}$ many countries have introduced measures to prevent or slow the spread of the virus, including lockdowns, border closures, and visa restrictions which significantly affected migration flows and trends. With the recent emergence of the Omicron variant (WHO 2021), ${ }^{2}$ many countries imposed travel bans and restrictions for travellers from a number of African countries which were hit especially hard by this variant.

As a result of these lockdowns, border closures and visa restrictions, the number of permanent migrants arriving in member countries of the Organisation for Economic Co-operation and Development (OECD) declined by more than $30 \%$ in 2020 to about 3.7 million, the lowest level since 2003 (OECD 2021). ${ }^{3}$ Similarly, the number of new asylum applications in OECD countries also fell by $31 \%$ in 2020 (ibid.). While it is still too early to assess the pandemic's long-term effects, a preliminary analysis shows that it has cut off mobility pathways, stranded migrants, destroyed

\footnotetext{
${ }^{1}$ WHO (World Health Organization). (2020). WHO Director-General's opening remarks at the media briefing on COVID-19 - 11 March 2020. WHO, 11 March [webnews]. Geneva: WHO. Retrieved 27 Dec 2021 from https://www.who.int/director-general/speeches/detail/who-director-general-s-opening-remar ks-at-the-media-briefing-on-covid-19---11-march-2020

${ }^{2}$ WHO (World Health Organization). (2021). Classification of Omicron (B.1.1.529): SARS-CoV-2 variant of concern. WHO, 26 November 2021 [online statement]. Geneva: World Health Organization. Retrieved 27 Dec 2021 from https://www.who.int/news/item/26-11-2021-classification-of-omicron-(b.1. 1.529)-sars-cov-2-variant-of-concern

${ }^{3}$ OECD (Organisation for Economic Co-operation and Development). (2021). International migration outlook 2021. Paris: OECD. Retrieved 27 December 2021 from https://www.oecd.org/migration/inter national-migration-outlook-1999124x.htm
}

Shibao Guo

guos@ucalgary.ca

1 Werklund School of Education, University of Calgary, Calgary, AB, Canada 
jobs and income, reduced remittances and pushed millions of migrants and vulnerable populations into poverty (ICMPD 2021). ${ }^{4}$ In addition, we have also witnessed a surge in racism and xenophobia in countries like Canada where immigrants and refugees are said to be welcome (Guo and Guo 2021). ${ }^{5}$

Despite the major setbacks in human mobility, the global pandemic has not put an end to transnational migration. In fact, prior to the arrival of COVID-19, the world has made remarkable progress with migration over the last two decades. It is estimated that in 2020, about 281 million people, or $4 \%$ of the world population, lived outside their countries of birth, up from 173 million in 2000 (UN DESA 2020) ${ }^{6}$. Nearly two-thirds of all transnational migrants live in high-income OECD countries, with the United States featuring as the largest single destination country (51 million) followed by Germany (16 million). By contrast, low- and middle-income countries located primarily in Northern Africa, Western Asia and sub-Saharan Africa hosted $80 \%$ of the world's refugees and asylum seekers in 2020, which doubled from 17 to 34 million over the past two decades (ibid.). The same report also indicates that India has the largest transnational community in the world, reaching 18 million in 2020, followed by the Russian Federation (11 million), China (10 million), and the Syrian Arab Republic (8 million). It is important to note that women comprise slightly less than half of all transnational migrants, sitting at $48 \%$ in 2020 . As a result of growing migration, the foreign-born population of OECD countries rose to 136 million or $14 \%$ of the total population in 2020 , up from $11.9 \%$ in 2010 at an increase of $2.5 \%$ per year since 2000 (OECD 2021). It seems evident that migration has brought significant changes to the demographics and socio-cultural fabric of receiving societies.

In addition, the international community has made significant progress with transnational migration with the passing of a series of landmark agreements, including the New York Declaration for Refugees and Migrants (UN 2016); ${ }^{7}$ the Global Compact for Safe, Orderly and Regular Migration (UN 2018a); ${ }^{8}$ and the Global

\footnotetext{
4 ICMPD (International Centre for Migration Policy Development) (2021). ICMPD Migration Outlook 2021: Seven things to look out for in 2021. Origins, key events and priorities for Europe. Vienna: ICMPD. Retrieved 27 December 2021 from https://www.icmpd.org/file/download/50555/file/ICMPD 0Migration0Outlook020210EN.pdf

5 Guo, S., \& Guo, Y. (2021). Combating anti-Asian racism and xenophobia in Canada: Toward pandemic anti-racism education in post-COVID-19. Beijing International Review of Education, 3(2), 187211. https://doi.org/10.1163/25902539-03020004

${ }^{6}$ UN DESA (United Nations Department of Department of Economic and Social Affairs). (2020). International migration 2020 highlights. ST/ESA/SER.A/452. New York: UN DESA. Retrieved 27 Dec 2021 from https://www.un.org/development/desa/pd/sites/www.un.org.development.desa.pd/files/undesa_pd_ 2020_international_migration_highlights.pdf

7 UN (United Nations). (2016). New York declaration for refugees and migrants. United Nations A/ RES/71/1. New York: UN. Retrieved 27 December 2021 from https://www.un.org/en/development/desa/ population/migration/generalassembly/docs/globalcompact/A_RES_71_1.pdf

${ }^{8}$ UN (United Nations). (2018a). Global compact for safe, orderly and regular migration (The Global Compact for Migration). Final draft, 11 July 2018. New York: United Nations. Retrieved 27 Dec 2021 from https://refugeesmigrants.un.org/sites/default/files/180711_final_draft_0.pdf
} 
Compact for Refugees (UN 2018b). ${ }^{9}$ These resolutions were adopted by the General Assembly of the United Nations (UN) to enhance international cooperation on migration and refugee resettlement in all dimensions, recognising that large movements of refugees and migrants are global phenomena that need global approaches and solutions. The international community also recognises the many common challenges and struggles facing migrants and refugees, and has agreed to protect the human rights and fundamental freedoms of all refugees and migrants, particularly migrant and refugee women and girls. Collectively, the global world strongly condemns acts and manifestations of racism, and commits to eliminating all forms of discrimination, xenophobia and intolerance against migrants and refuges. To help migrants and refugees improve their integration and inclusion in the host societies, it is acknowledged that measures need to be taken to enhance their employment opportunities and access to education, health care and social services. Since such frameworks are not legally binding, it is not clear, however, how each country implements these commitments and how they will be held accountable if these commitments are not met.

Despite these lofty ideas and bold statements, many transnational migrants and refugees still face multifaceted obstacles in adapting to a new society, with language and employment as the most frequently cited barriers. UNESCO's Global Education Monitoring Report 2019 (UNESCO, 2018) ${ }^{10}$ reveals that migrants, refugees and internally displaced people still remain some of the most vulnerable people in the world, and that our current laws and policies are failing them by negating their rights and ignoring their needs. The report also indicates that provision of education in itself is not sufficient. In particular, the education needs of adult migrants and refugees are often neglected. Many of them experience deskilling and devaluation of their prior learning and work experience upon arrival, causing them to struggle in their efforts to transition into work and learning in their host society (Guo 2010, 2015). ${ }^{11}$ In the context of Canada, for example, despite the fact that immigrants bring significant human capital resources to the Canadian labour force, many have suffered unemployment and underemployment, poor economic performance and downward social mobility. Recent immigrants' negative experience in Canada can be attributed to a triple glass effect, including a glass gate, glass door, and glass ceiling, which may converge to create multiple structural barriers affecting immigrants' new working lives at different stages of their integration and transition processes

\footnotetext{
${ }^{9}$ UN (United Nations). (2018b). Global compact on refugees. United National General Assembly official record A/73/12 (Part II). United Nations. Retrieved 27 Dec 2021 from https://www.unhcr.org/gcr/ GCR_English.pdf

10 UNESCO (United Nations Educational, Scientific and Cultural Organization). (2018). Migration, displacement and education: Building bridges, not walls. Global education monitoring report 2019. Paris: UNESCO. Retrieved 27 Dec 2021 from https://unesdoc.unesco.org/ark:/48223/pf0000265866

11 Guo, S. (2010). Toward recognitive justice: Emerging trends and challenges in transnational migration and lifelong learning. International Journal of Lifelong Education, 29(2), 149-167. https://doi.org/10. 1080/02601371003616533, Guo, S. (2015). The colour of skill: Contesting a racialised regime of skill from the experience of recent immigrants in Canada. Studies in Continuing Education, 37(3), 236-250. https://doi.org/10.1080/0158037X.2015.1067766
} 
(Guo 2013). ${ }^{12}$ From this perspective, adult and lifelong learning has a critical role to play in fulfilling the fourth Sustainable Development Goal (SDG 4) in the UN 2030 Agenda to "ensure inclusive and equitable quality education and promote lifelong learning opportunities for all" and to "leave no one behind" (UN 2015). ${ }^{13}$

Against this backdrop, this special issue of the International Review of Education - Journal of Lifelong Learning revisits challenges and opportunities for lifelong learning in the context of transnational migration and refugee studies. In this special issue, the mobility of migrants and refugees is conceptualised as circulatory and transnational rather than unidirectional, moving us beyond the framework of methodological nationalism (Guo 2010). The compilation aims to extend the scope and meaning of transnational mobility, especially as it pertains to divergent communities such as migrants, refugees and asylum seekers. The collection comprises nine outstanding articles by scholars from four different countries in rethinking the relationship between mobility, knowledge, diversity, inclusion and lifelong learning in the context of transnational migration.

The first article, "Navigating transition to work: Recent immigrants' experiences of lifelong learning in Canada" by Jingzhou Liu and Shibao Guo, opens the special issue with an examination of recent immigrants' transition to work in Canada and the role of lifelong learning in this process. Adopting intersectionality as its theoretical framework and institutional ethnography as its methodology, this qualitative study focused on how race, gender and class intersect in shaping immigrants' experiences of transition to work. The researchers focused on the experience of immigrant settlement workers (ISWs) who were themselves immigrants from racialised minority backgrounds and who worked with immigrants to facilitate their settlement and integration in Canada. Despite the fact that well-educated immigrants bring significant human capital resources to Canada, many of the study's respondents reported encountering multilayered structural barriers in accessing the Canadian labour market. Taking ISWs' lived experiences as an entry point, Liu and Guo scrutinise how immigrants' daily practices are related to or shaped by institutional relations. Their findings reveal that in in order to obtain recognition of their international credentials and professional experiences, ISWs have to go through processes of recredentialling that are governed by an institutional complex positioned in structures of power that shape the institutional ruling relations (Smith 2005). ${ }^{14}$ The racialised institutional operation and the colonising practices, Liu and Guo argue, elucidate a hierarchical regime of knowledge that deepens racialised immigrants' social stratification,

\footnotetext{
12 Guo, S. (2013). Economic integration of recent Chinese immigrants in Canada's second-tier cities: The triple glass effect and immigrants' downward social mobility. Canadian Ethnic Studies, 45(3), 95-115. https://doi.org/10.1353/ces.2013.0047

13 UN (United Nations). (2015). Transforming our world: The 2030 Agenda for sustainable development. New York: United Nations. Retrieved 27 Dec 2021 from https://sustainabledevelopment.un.org/post2 015/transformingourworld/publication

14 According to Canadian sociologist Dorothy E. Smith, ruling relations coordinate people's social relations locally and translocally through "objectified forms of consciousness and organization, constituted externally to particular people and places" (Smith 2005, p. 227). Smith, D. E. (2005). Institutional ethnography: A sociology for people. Altamira Press.
} 
exclusion and marginalisation. In light of their findings, the authors propose an anticolonial and anti-racism approach that aims to decolonise the current ideological moorings of lifelong learning theories, policies and practices in the age of transnational migration.

In the second article, "Resisting the soft skills discourse: Perspectives and experiences of internationally educated nurses in Canada", Marcia Kim and Yan Guo continue the examination of immigrants' transition to work in Canada by focusing on the experience of internationally educated nurses (IENs). As Canadian society becomes more ethno-culturally diverse, an increasing number of IENs have joined the Canadian healthcare workforce, and it has thus become imperative to build more socio-culturally inclusive workplaces. In conducting their study, the authors adopted narrative inquiry as their research methodology and the life story interview as their research method to examine IENs' lived experiences. The concept of governmentality (Foucault 2007) ${ }^{15}$ provided a theoretical framework to help understand the relationship between nurses, soft skills and power that flow through all aspects of nursing and patient care. Kim and Guo's analysis demonstrates how IENs problematise the deficit discourse of soft skills involved in their own employment preparedness. Questioning the separation of soft skills from nursing procedures, IENs advocate a holistic whole-person approach attending to patients' physical, psychological and spiritual needs. IENs also confront the English-only policy in nursing and propose instead the active use of transcultural knowledge and multilingual skills to meet the needs of patients from culturally diverse backgrounds. Through deconstructing the discourse of soft skills, Kim and Guo's study illustrates how skill as an ideology is socially constructed, serving as an instrument of control to govern IENs' nursing practices. It also demonstrates the agency of IENs in developing culturally responsive healthcare in Canada.

In the next article, "Fostering diversity work as a process of lifelong learning: A partnership case study with an immigrant services organisation", Hongxia Shan, Amy Cheng, Nasim Peikazadi and Yeonjoo Kim explore diversity work as a process of lifelong learning at an immigrant services organisation in Vancouver. Unlike existing research which focuses on challenges and problems of diversity initiatives, the study conducted by Shan et al. examined diversity practices that foster social equity and inclusion. Adopting a partnership case study approach, the study was guided by two primary research questions examining organisational approaches to diversity management and training and the learning experiences of staff members related to diversity work. The researchers' findings point to a learning curriculum that has contributed to building a diverse organisation, supporting lifelong learning

\footnotetext{
15 French philosopher Michel Foucault (2007) describes governmentality as "the conduct of conduct" to capture the idea that people in modern society are led or "conducted" in some way (ibid., p. 193), and that they are "subjected to a multitude of governing practices that aim to discipline and normalize all aspects of human experience" (Darbyshire and Fleming 2007, p. 173). Foucault, M. (2007). Security, territory, population: Lectures at the Collège de France 1977-1978 (edited by M. Senellart, translated by G. Burchell). London: Palgrave Macmillan. Darbyshire, C., \& Fleming, E. M. (2007). Governmentality, student autonomy and nurse education. Journal of Advanced Nursing, 62(2), 172-179. https://doi.org/10. 1111/j.1365-2648.2007.04571.x
} 
at work, and providing diversity training that is directive and yet generative. This study sheds new light on the organisational practices constitutive of frontline workers' diversity learning work that is generative of productive and collective reflection.

In the fourth article, "Conceptualising a holistic model of transcultural lifelong learning", Sinela Jurkova and Shibao Guo take up some of the themes discussed by Shan et al. Jurkova and Guo's contribution explores transcultural learning as a holistic model of lifelong learning. More specifically, they focus on how adult learners acquire transcultural knowledge and expertise through participation in different lifelong learning activities and how transcultural learning empowers adult learners and transforms their perspectives. Choosing transculturation as the theoretical framework for their study enabled the researchers to reflect their respondents' engagement in a new way of seeing the world and imply diffusion of multiple cultural identities as individuals crossed the borders of various cultures and interacted with them. Drawing on a qualitative research design, the authors conducted semi-structured indepth interviews and focus group discussions with Canadian-born and immigrant adults who described how different lifelong learning activities had impacted their transcultural learning. Drawing on their respondents' experiences, Jurkova and Guo conceptualise a holistic model of transcultural lifelong learning categorised into three dimensions: cognitive, affective and social. The authors maintain that adopting a holistic process of transcultural lifelong learning can create a more inclusive environment for lifelong learning without opposing cultural, national and ethnic binaries. A framework of transcultural lifelong learning, Jurkova and Guo suggest, has the potential of opening new horizons of cultural interaction and active participation in an increasingly diverse learning environment in the age of transnational migration.

With the next article, "Towards social justice and equity in English as an Additional Language (EAL) policies: The agency of immigrant parents in language policy advocacy in Alberta schools", Yan Guo turns our attention to language policy in Canada and the agency of immigrant parents in language policy advocacy. As Canada's population becomes more ethno-culturally diverse, there has been a growing number of English as an Additional Language (EAL) students in Canadian public schools. In this context, the author first highlights a number of systemic inequities in EAL policies and programmes, including reduction and diversion of EAL funding, inadequate EAL programming and Eurocentric curricula. Grounding her study in critical language policy theory, Guo adopted a case study approach involving semistructured interviews and focus group discussions with immigrant parents and community activists who were concerned and vocal about immigrant children's language and educational rights. Based on participants' experiences and perspectives, the author documents two forms of advocacy that immigrant parents undertook: organised advocacy based on formal, collective school alliance and network building; and everyday advocacy constituting more subtle, individual critiques about unjust policies and practices within the Canadian school system. This advocacy work emerged from informal learning that was intentional and emancipatory as parents sought to find out about policies and then joined others to exercise their rights on behalf of their children. By bringing new voices of immigrant parents into the educational policy process, Guo's study challenges the deficit perspective that school officials 
often apply to parents of EAL learners. Her findings provide directions for EAL policies, programmes and services, as well as new insights into the effectiveness of advocacy and capacity building of parents of EAL learners.

In the sixth article, "To choose not to be included: Critical perspectives on practices of inclusion with adult immigrant students", Katherine E. Entigar brings forward critical thinking about inclusion in education with adult immigrant learners of English as a Second Language (ESL) in New York City. Entigar begins the discussion with a review of the term "inclusion" in education which has historically been applied as a corrective to the exclusion of marginalised groups from educational opportunities and spaces. She points out, however, that inclusion of immigrants in formalised adult education has been largely ignored in research. Hence, she decided to conduct a sequential mixed methods study with adult ESL learners at an Immigrant Learning Network in New York City involving a survey and two interactive focus groups. Entigar's findings reveal that her participants expressed feelings of offence at being subjected to national and cultural stereotyping in "inclusive" class discussions. They argued that the decisions of adult immigrant learners to participate - or not - in inclusive activities should be respected. They also pointed out that for adult learners who had arrived as refugees or asylum seekers, inclusion, despite being well-intentioned, could actually be invasive and potentially (re)traumatising. The findings provoke questions that require intersectional, disruptive and even creative thinking on the part of educators. To develop inclusive and critically reflective teaching and learning practices in adult education with immigrant learners, Entigar suggests a new framework for conceptualising inclusion in education by employing politically engaged notions of unknowing, politicised trust and coalition thinking.

In the next article, "The promise of refugee lifelong education: A critical review of the field", Linda Morrice shifts the focus to refugee lifelong education. She begins by pointing out that much of the early focus of refugee education has been on primary and secondary education, and that only recently more attention has been paid to the role of lifelong education for refugee youth and adults. To lay the groundwork for a critical analysis, Morrice argues that the intersection of the study of refugees and education requires a critical framing, with both "refugee" and "lifelong education" opened to question and interrogation. Framing the discussion from a postcolonial perspective, the author first problematises the concepts and categories of "refugee" and "nation states" which have assumed a taken-for granted naturalness rendering invisible the purpose such categories serve. By locating refugee studies within the colonial legacies and postcolonial logics of the European nation state, her analysis shows how the international refugee regime is inseparably bound to the European colonial project. Then she traces the rise of lifelong education as a priority in humanitarian contexts and argues that a conceptualisation of lifelong education for refugees is needed to bridge the gap between disrupted schooling on the one hand and future aspirations of self-reliance and participation in society on the other. In conclusion, the author suggests a critical approach to refugee lifelong education which recognises the ways in which the colonial past is still active in the inequalities of the present.

In the eighth article, "Recognition and precarious mobilities: The experiences of university students from a refugee background in Australia", Susan Webb, 
Karen Dunwoodie, Jane Wilkinson, Luke Macaulay, Kristin E. Reimer and Mervi Kaukko continue with the theme of refugee education by focusing on the experiences of university students from a refugee background in Australia. This article focuses on university students from asylum-seeking backgrounds as a distinct and scarcely researched group within the category of forced migration and explores how they experience higher education. The discussion is well situated in the context of Australian higher education where the number of students from refugee and asylum-seeking backgrounds has increased in recent years. Grounded in the concept of recognition, the authors conducted a qualitative longitudinal narrative enquiry exploring the experiences of 22 students from asylum-seeking backgrounds in a Bachelor's degree programme. Their findings highlight participants' understanding and interpretation of barriers and concerns, their sense of identity and belonging, and their experiences of connectedness and support. The study sheds new light on the precariousness of their experiences and the importance of giving voice to students' views.

In the final article, "Media and government framing of asylum seekers and migrant workers in Canada during the COVID-19 pandemic", Michelle Stack and Amea Wilbur critically examine media coverage on asylum seekers and news statements as well as press releases from the Canadian government during COVID-19. Their analysis of material issued between 1 March and 10 December 2020 is guided by two primary research questions focusing on the discursive frames in the construction of asylum seekers and migrants who provided care and services to Canada during the pandemic and the representation of their skills and abilities. The authors use critical discourse analysis to probe categories such as "refugee" in understanding who is categorised as a refugee and who has the power to speak and to define. Their analysis also demonstrates how asylum seekers, migrant workers and their allies produced and disseminated counter narratives in challenging the long-standing discursive framings of asylum seekers as benefactors of Canadian generosity, criminals, burdens or victims during the first ten months of COVID-19. In conclusion, Stack and Wilbur propose pedagogical spaces for critical transnational lifelong media education that engage with the work and specific campaigns for justice of social movements.

Taken together, this special issue enriches our understanding about the changing dynamics and complexities of transnational migration, refugee studies and lifelong learning. Because most research presented in the special issue was conducted before COVID-19 broke out, more studies are needed to explore the implications of the COVID-19 pandemic transnational migration and refugee studies. I wish to thank all authors for their outstanding contributions. I would also like to express my appreciation and thanks to Paul Stanistreet and Maya Kiesselbach at the UNESCO Institute for Lifelong Learning for their help and support throughout the whole process.

Publisher's Note Springer Nature remains neutral with regard to jurisdictional claims in published maps and institutional affiliations. 
Shibao Guo (郭世宝), PhD, is a Professor at the Werklund School of Education, University of Calgary. He specialises in comparative and international education, internationalization of higher education, transnational migration and diaspora, ethnic and race relations, and lifelong learning. His latest books include: Decolonising lifelong learning in the context of transnational migration (Routledge, 2020), Immigration, racial and ethnic studies in 150 years of Canada (BrilllSense, 2018), Work, learning and transnational migration (Routledge, 2016), Spotlight on China: Chinese education in the globalized world (Sense Publishers, 2016). He is former president of the Canadian Ethnic Studies Association (CESA) and the Comparative and International Education Society of Canada (CIESC). Currently he serves as co-editor of Canadian Ethnic Studies. He also edits two book series for BrilllSense Publishers: Transnational Migration and Education, and Spotlight on China. 